\title{
The Effect Of The Relationships Between Organisations And Their Suppliers On The Implementation Of Purchasing Marketing Strategies
}

\author{
Matjaž Iršič, (E-mail: irsic@uni-mb.si), University of Maribor, Slovenia
}

\begin{abstract}
The article deals with different factors determining relationships of large Slovenian organisations (with over 500 employees) with their strategic suppliers and their influence on the frequency of implementations of purchasing marketing strategies. The factors dealt with are: the quality of the relationship between the organisation and its strategic supplier (suppliers activities, attractiveness of supply for the organisation and the competitive position of the organisation on the supply market), bargaining power of the organisation with respect to the supplier (the organisation's risk orientation, its orientation towards cooperation and the size of its bargaining power) and the quantity of the relationship (the size of transactional assets). The research showed that large organisations in Slovenia are unlikely to develop such purchasing marketing strategies characteristic of the so-called »relationship marketing « with their strategic suppliers, with which they have long-term business relationship. The influence of measured factors on the frequency of the implementation of individual purchasing marketing strategies exists, with a stronger impact of factors with short-term effects on the organisation; hence the surveyed organisations are still more oriented towards reaching short-term efficiency instead of long-term success.
\end{abstract}

\section{THEORETICAL FRAMEWORK}

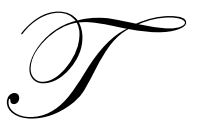

he starting point of the "new" paradigm of marketing in the 21 st century is based on interactive connections among market players, taking into account the "diadic" relationship between two organisations (Anderson, Hakansson, Johanson; 1994; Anderson and Weitz, 1989; Dwyer, Schurr and

Oh, 1987; Gummesson, 1995; Low, 1995; Payne, 1995; Han, Wilson and Dant, 1993; Wathne, Heide, 2004; Bergen, Dutta, Walker, 1992; Cannon and Perreault, 1999; Iacobucci, 1996; Levy and Grewal, 2000).

This also holds true for the purchasing marketing, where the use of developed marketing concepts on the supply markets places organisations in a more balanced position against the aggressive forms of sales marketing of potential and existing suppliers. The rearrangement of the exchange (bargaining) power among market players in such relationships, as well as the rearrangement of action parameters determining such market power, necessitates a redefinition and reshaping of basic strategic approaches of an organisation on the supply market.

The use of external purchasing resources based on a long-term, profound and active relationship with the supplier (the concept of "relationship marketing") challenges traditional market concepts regarding business activities of organisations on purchasing markets and classical approaches to the understanding of the distribution of action parameters determining the bargaining power of partners. Efficient and successful creation of purchasing marketing strategies in such circumstances necessitates profound understanding of these relationships, the necessary conditions for their development, their advantages and disadvantages, as well as the effects of activities involved. 
By connecting findings and statements expressed by numerous authors (Dwyer, Schurr, Oh, 1987; Gummesson, 1995; Morgan, Hunt, 1994; Payne, 1994; Low, 1996, Johnson and Selnes, 2004; Anderson and Narus, 1990; etc.) studying relationships, and by adding our own findings, it can be said that relationships - the basic postulate of the concept of "relationship marketing" - have the following determinants: cooperation and other forms of mutual interaction between at least two participants in a transactional process or between at least two networks (partner groups), mutual attainment of goals by all participants ("win-win" strategy), multiple and continuing exchange of value (products, activities, competences, status, roles and significance), balancing mutual benefits and a tendency towards minimising business risk.

Regardless of the differences in defining the relationship and the concept of "relationship marketing" among different authors (Jackson 1985; Thorelli 1986; Dwyer, Schurr, Oh 1987; Christopher, Payne and Ballantyne, 1991; Morgan and Hunt 1994; Gummesson 1995; etc.) all definitions have one thing in common, namely that in developing and implementing the concept of "relationship marketing" it is necessary to take into account two theoretical concepts: the theory of transactional costs as an alternative theory of microeconomics and the "commitment-trust" theory as an important behavioural organisation theory.

\section{RESEARCH}

\section{Research Problem And The Empirical Model}

It is reasonable to try to find out how the key factors determining the relationship with a strategically important supplier influence the frequency of the implementation of purchasing marketing strategies and if these strategies belong to the classical (traditional) buyer-supplier relationships and transactional marketing ${ }^{1}$ or if they belong to the purchasing marketing pointing towards a closer connection between the participants (i.e. are closer to the concept of relationship marketing) for organisations with a marketing orientation on the purchasing market that are establishing long-term relationships with their strategic suppliers, i.e. they practice the concept of "relationship marketing" on their most important purchasing markets.

The research problem was studied on a sample of organisations from Slovenia. Our research is based on an empirical model, in which the key studied relationships and interdependencies are shown in figure 1.

The relationship in our model is represented by the function of three groups of independent variables (X):

- $\quad$ quality values of the relationship (X1),

- $\quad$ bargaining power with regard to the supplier and manoeuvring space (X2) and

- $\quad$ quantity values of the relationship (X3):

$\mathrm{X}=\mathrm{f}(\mathrm{X} 1, \mathrm{X} 2, \mathrm{X} 3)$.

The quality value of the relationship (X1) is a function of two variables: assessment of the strategic supplier (X11) and the role of organisation on the purchasing market with regard to the strategic supplier (X12):

$X 1=f(X 11, X 12)$.

The assessment of the strategic suppliers (X11) is done on the basis of nine factors: supplier's capacity, location, supplier's financial status, technology, management, quality of products, delivery in due time, purchase price and supplier's ability to meet the market requirements:

$\mathrm{X} 11=\mathrm{f}(\mathrm{X} 111, \mathrm{X} 112, \ldots, \mathrm{X} 119)$.

\footnotetext{
${ }^{1}$ We understand »traditional « buyer-supplier relationship as a discrete transactional relationship through which the participants take into the account mostly short-term tactical exchanging objectives, based on »win-lose« strategy.
} 
Figure 1: Empirical Model Of Relations In The Research

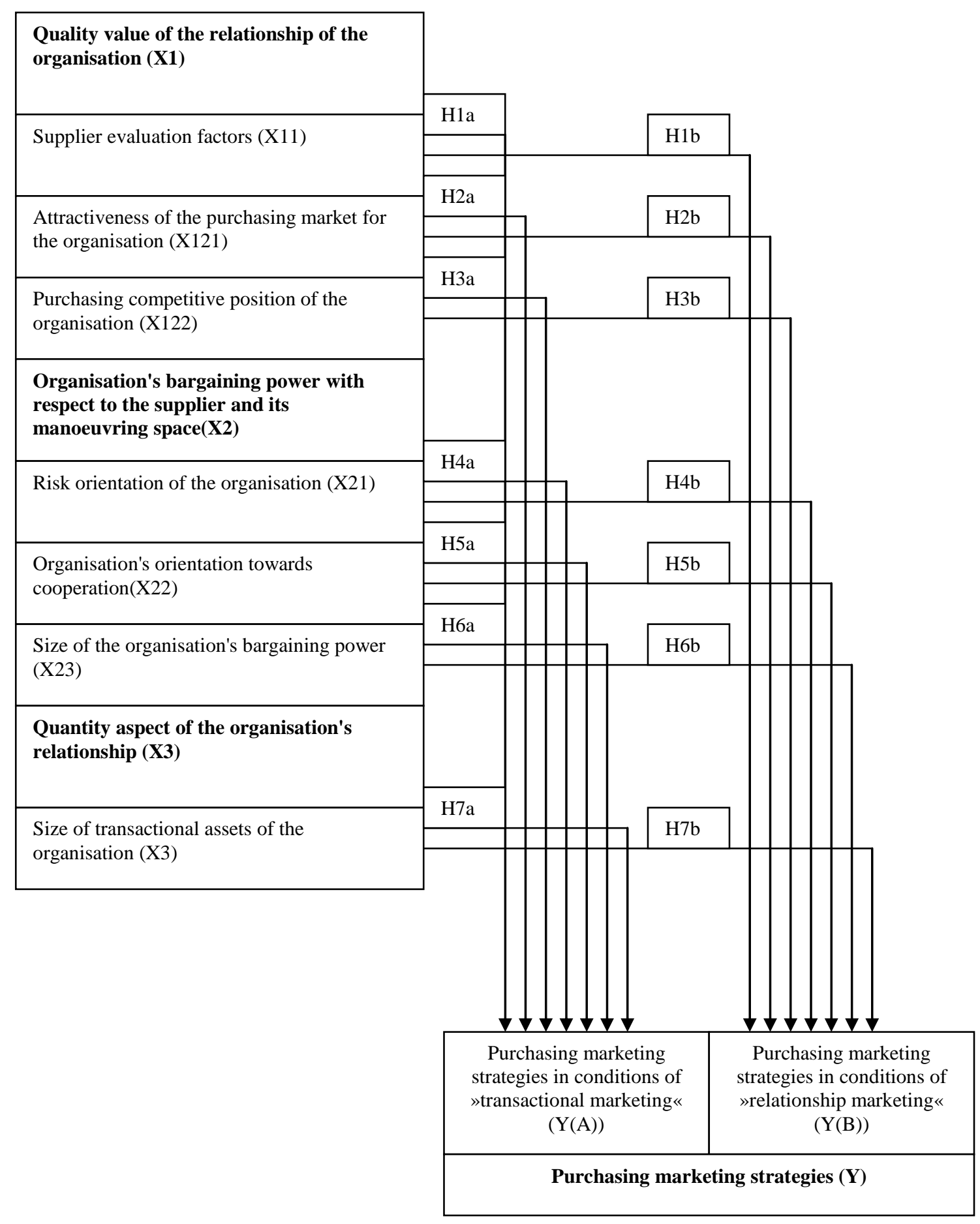

The role of the organisation on the purchasing market with regard to its strategic supplier (X12) is understood as a strategic position of the organisation with regard to the attractiveness of the purchasing market for the organisation (X121) and its competitive position or market power (X122): 
$\mathrm{X} 12=\mathrm{f}(\mathrm{X} 121, \mathrm{X} 122)$.

In assessing the attractiveness of the purchasing market for an organisation, the following seven factors were considered: the size of the purchasing market or the availability of substitutes, the growth level of the purchasing markets, its structure, stability of the demand, obstacles for entering the industry (entry barriers), obstacles for exiting the industry (exit barriers), and the possibility for a vertical integration of the organisation in the previous stage:

$\mathrm{X} 121=\mathrm{f}(\mathrm{X} 1211, \mathrm{X} 1212, \ldots, \mathrm{X} 1217)$.

With regard to the competitive position or power of an organisation in relationship to its strategic supplier, eight factors were considered: purchasing potential, "switching" costs, the ratio between supply costs and total purchasing value, the growth of purchases, success of marketing communication, image assessment, marketing information of the organisation, and price elasticity of demand:

$\mathrm{X} 122=\mathrm{f}(\mathrm{X} 1221, \mathrm{X} 1222, \ldots, \mathrm{X} 1228)$.

Bargaining power of the organisation with regard to its supplier and manoeuvring space (X2) is a function of four variables (factors): risk orientation of the organisation (X21), organisation's orientation towards cooperation (X22), power or reliability of the organisation on its strategic supplier (X23). At the same time, bargaining power of an organisation will be understood as a function of the organisation's competitive position or its business power (X122), which is also a part of quality value of the relationship (X1). The expanded relation can be put down as:

$\mathrm{X} 2=\mathrm{f}(\mathrm{X} 21, \mathrm{X} 22, \mathrm{X} 23, \mathrm{X} 122)$.

Quantity value of the organisation's relationship with its strategic supplier or the company's size of transactional assets (X3) is a function of seven variables (factors): the structure of products the organisation is exchanging with the supplier (X31), duration of the relationship with the chosen supplier (X32), organisation's cooperation with the supplier in the field of product development (X33), organisation's cooperation with the supplier in the field of technology (X34), organisation's cooperation with the supplier in the field of management (X35), similarity between the organisation and its supplier with regard to values and corporate culture (X36), similarities between the organisation and its supplier with regard to the level of technological development (X37):

$\mathrm{X} 3=\mathrm{f}(\mathrm{X} 31, \mathrm{X} 32, \ldots, \mathrm{X} 37)$.

Our research is aimed at finding the connection between the mentioned groups of factors i.e. independent variables (X1, X2 in $\mathrm{X} 3$ ), which shape the relationship between the organisation on the purchasing market and the purchasing marketing strategies, which represent a group of dependent variables (Y).

The empirical model of purchasing marketing strategies, and their investigated frequency of implementation, is based on individual instruments of purchasing marketing (i.e. functional or instrumental purchasing marketing strategies): strategies regarding the product (purchasing object), strategies regarding prices and purchasing terms, strategies regarding ordered quantities and the size of stock, strategies regarding the number of sources of supply, strategies regarding processes related to the supplier and processes regarding communication with the chosen supplier:

$\mathrm{Y}=\mathrm{f}(\mathrm{Y} 1, \mathrm{Y} 2, \ldots, \mathrm{Y} 25)$.

The model is comprised of 25 strategies which include both strategies that prevail in conditions of classical buyer-supplier relationships »transactional « marketing $(\mathrm{Y}(\mathrm{A}))$ and strategies that are characteristic to organisations on the purchasing market which implement the concept of »relationship marketing $\ll(\mathrm{Y}(\mathrm{B}))^{2}$.

\footnotetext{
${ }^{2}$ See figure 1.
} 


\section{Research Goals}

On the basis of preliminary research findings and on the basis of the empirical model presenting relationships between factors shaping the relationships and purchasing marketing strategies (Figure 1) the following research goals were set:

To find out what is the correlation between the level of weighted calculation of factors used for measuring the level of attractiveness of the existing strategic suppliers for an organisation and the frequency of the implementation of individual purchasing marketing strategies, the following research hypotheses were formulated:

H1a: There is a negative correlation between the weighted calculation of the majority of factors, with which the level of the attractiveness of the existing strategic suppliers and the frequency of implementation of purchasing marketing strategies that are characteristic of and prevailing in conditions of classical buyersupplier relationships between organisations and suppliers (i.e. in conditions of transactional marketing) were measured.

H1b: There is a positive correlation between the weighted calculation of the majority of factors with which the level of attractiveness of the existing strategic suppliers and the frequency of implementation of purchasing marketing strategies that are characteristic of and prevailing in conditions of the concept of »relationship marketing.

To find out what is the correlation between factors used for the degree of attractiveness of purchasing market for an organisation and the frequency of implementation of individual purchasing marketing strategies, the following research hypotheses were formulated:

H2a: There is a positive correlation between the degree of attractiveness of the purchasing market of an organisation (i.e. between the majority of factors used for measuring the degree of attractiveness) and the frequency of implementation of those purchasing market strategies, which are characteristic of and prevailing in conditions of classical buyer-supplier relationships between organisations and suppliers (i.e. in conditions of »transactional marketing).

H2b: There is a negative correlation between the degree of attractiveness of the purchasing market of an organisation (i.e. between the majority of factors used for measuring the degree of attractiveness) and the frequency of implementation of those purchasing marketing strategies, which are characteristic of and prevailing in conditions of the concept of relationship marketing.

To find out if there is a correlation between the factors used for assessing the competitive position of an organisation and the frequency of implementation of individual purchasing marketing strategies, the following research hypotheses were formulated:

H3a: There is a positive correlation between the competitive position (i.e. between the majority of factors used for measuring the degree of attractiveness) and the frequency of implementation of those purchasing marketing strategies, characteristic for and prevailing in the conditions of classical buyer-supplier relationships of an organisation with a supplier (i.e. in conditions of $\gg$ transactional marketing).

H3b: There is a negative correlation between the competitive position (i.e. between the majority of factors used for measuring the degree of attractiveness) and the frequency of implementation of those purchasing marketing strategies, which are characteristic of and prevailing in conditions of the concept of relationship marketing.

To find out if there is a correlation between the factors used for assessing the degree of risk orientation and the frequency of implementation of individual purchasing marketing strategies, the following research hypotheses were formulated:

H4a: There is a positive correlation between the degree of risk orientation of an organisation (i.e. between the majority of factors used for measuring this factor) and the frequency of implementation of those purchasing 
marketing strategies, characteristic for and prevailing in the conditions of classical buyer-supplier relationships of an organisation with a supplier (i.e. in conditions of transactional« marketing).

H4b: There is a negative correlation between the degree of risk orientation of an organisation (i.e. between the majority of factors used for measuring this factor) and the frequency of implementation of those purchasing marketing strategies, which are characteristic of and prevailing in conditions of the concept of relationship marketing .

Find out if there is a correlation between the factors used for assessing the degree of organisation's orientation towards cooperation and the frequency of implementation of individual purchasing marketing strategies, the following research hypotheses were formulated.

H5a: There is a negative correlation between the degree of company's orientation towards cooperation (i.e. between the majority of factors used for measuring this factor) and the frequency of implementation of those purchasing marketing strategies, characteristic for and prevailing in the conditions of classical buyer-supplier relationships of an organisation with a supplier (i.e. in conditions of transactional marketing).

H5b: There is a positive correlation between the organisation's orientation towards cooperation (i.e. between the majority of factors used for measuring this factor) and the frequency of implementation of those purchasing marketing strategies, which are characteristic of and prevailing in conditions of the concept of relationship marketing .

Find out if there is a correlation between the factors used for assessing the degree of bargaining (transactional) power of the buyer in relation to its strategic supplier and the frequency of implementation of individual purchasing marketing strategies with the following research hypotheses:

H6a: There is a positive correlation between the degree of bargaining (transactional) power (i.e. between the majority of factors used for measuring the degree of bargaining power of an organisation) and the frequency of implementation of those purchasing marketing strategies, characteristic for and prevailing in the conditions of classical buyer-supplier relationships of an organisation with a supplier (i.e. in conditions of $»$ transactional $\ll$ marketing).

H6b: There is a negative correlation between the degree of bargaining (transactional) power (i.e. between the majority of factors used for measuring the degree of bargaining power of an organisation) and the frequency of implementation of those purchasing marketing strategies, which are characteristic of and prevailing in conditions of the concept of »relationship marketing .

Find out if there is a correlation between factors used for measuring the size of transactional assets of organisations (i.e. the number of transactional values in a relationship between an organisation and its supplier) and the frequency of implementation of individual purchasing marketing strategies with the following research hypotheses:

H7a: There is a negative correlation between the size of transactional assets (i.e. between the majority of factors used for measuring the size of organisation's transactional assets) and the frequency of implementation of those purchasing marketing strategies, characteristic for and prevailing in the conditions of classical buyersupplier relationships of an organisation with a supplier (i.e. in conditions of transactional marketing).

H7b: There is a positive correlation between the size of transactional assets (i.e. between the majority of factors used for measuring the size of organisation's transactional assets) and the frequency of implementation of those purchasing marketing strategies, which are characteristic of and prevailing in conditions of the concept of »relationship marketing «. 


\section{Research Methodology And Its Limitations}

\section{Sample And Data Collection}

All organisations with over 500 employees in Slovenia were included in our research (i.e. large organisations). There were 141 such organisations on December 31, 2003. The organisations were sent (their CEOs or presidents) a highly structured questionnaire that was returned by 90 organisations, whose answers were analysed.

The questionnaire consisted of four parts. In the first part, the respondents assessed the attractiveness of the existing strategic supplier with regard to their strategically most important purchased product(s), by at the same time taking into account some most important factors of attractiveness. In the second part, the respondents assessed the role of their organisation in the transactional process on the purchasing market with regard to their strategic supplier for the purchased product(s). They were asked to assess the attractiveness of the purchasing market and their competitive position on the market. In the third part, the respondents assessed the level of their bargaining power with regard to their strategic supplier, their manoeuvring space and the size of the transactional assets with regard to the chosen (analysed) strategic supplier. In the fourth part, the respondents were asked to identify the frequency of implementation of individual purchasing marketing strategies, stated in the questionnaire (the model of 25 strategies).

Data Processing And Analysis

SPSSX software was used for data processing, the research results are based on the use of descriptive statistics and discriminant analysis.

\section{Research Limitations}

The most significant limitations of this research relate to the possibly erroneous estimation regarding the difference between the ascertained characteristics of the surveyed sample of answers based on the returned questionnaires and the multitude of organisations with more than 500 employees in Slovenia.

The influence of relationship strategies of organisations on the frequency of implementations of purchasing marketing strategies was studied on the empirical model of independent variables (i.e. factors shaping the strategy of relationships of an organisation) and dependent variables (i.e. the model of 25 purchasing marketing strategies), which represents the next important research limitation.

The questionnaire was answered by CEOs (or presidents) of surveyed organisations, which can be considered subjective and not necessarily such as to describe the real situation within their organisations.

\section{Research Results}

Analysis Of The Frequency Of Implementation Of Purchasing Marketing Strategies

In the following table (table 1) we present the frequency of implementation of purchasing marketing strategies in the companies with more than 500 employees. 
Table 1: The Frequency Of Implementation Of Purchasing Marketing Strategies In Sampled Organisations

\begin{tabular}{|c|c|c|c|c|c|c|c|}
\hline \multirow[b]{2}{*}{ Purchasing Marketing Strategy } & \multirow{2}{*}{$\begin{array}{l}\text { No. Of } \\
\text { Strategy }\end{array}$} & \multirow[b]{2}{*}{ Type* } & \multirow[b]{2}{*}{$\mathbf{N}$} & \multirow[b]{2}{*}{$\mathbf{M}^{* *}$} & \multirow[b]{2}{*}{ SD } & \multicolumn{2}{|c|}{$\%$ Of Organisations } \\
\hline & & & & & & MIN*** & $\underset{*}{\operatorname{MAX} * * * *}$ \\
\hline \multicolumn{8}{|l|}{ Strategies related to the purchased object } \\
\hline $\begin{array}{l}\text { The strategy of instantaneous purchases based on } \\
\text { classical buyer-supplier relationships }\end{array}$ & Y1 & A & 90 & 3,24 & 1,300 & 26,7 & 50,6 \\
\hline $\begin{array}{l}\text { The strategy of cooperation with the supplier in the } \\
\text { development of a new product of the organisation (the } \\
\text { so-called "simultaneous engineering") }\end{array}$ & Y2 & B & 90 & 2,47 & 1,307 & 53,3 & 28,8 \\
\hline $\begin{array}{l}\text { Cooperation with the supplier in activities related to the } \\
\text { product launch, modification of an existing product or } \\
\text { removing products from the market }\end{array}$ & Y3 & B & 90 & 2,40 & 1,136 & 64,4 & 17,8 \\
\hline $\begin{array}{l}\text { The strategy of product standardisation, with an } \\
\text { alternative: purchased products are made according to } \\
\text { your specifications or plan }\end{array}$ & Y4 & $\mathrm{A}, \mathrm{B}$ & 90 & 3,29 & 1,236 & 26,6 & 57,8 \\
\hline $\begin{array}{l}\text { The strategy "Poka-Yoke" within the total quality } \\
\text { management (TQM) }\end{array}$ & Y5 & B & 90 & 3,49 & 1,392 & 20,0 & 53,3 \\
\hline \multicolumn{8}{|l|}{ Strategies related to price and purchasing terms } \\
\hline $\begin{array}{l}\text { The lowest purchasing price strategy with regard to } \\
\text { other potential supplier for a certain product }\end{array}$ & Y6 & $\mathrm{A}, \mathrm{B}$ & 90 & 4,07 & 0,915 & 4,4 & 77,8 \\
\hline The average market price strategy & Y7 & $\mathrm{A}$ & 90 & 2,82 & 1,193 & 35,6 & 33,3 \\
\hline The higher-than-average market price strategy & Y8 & A & 90 & 1,44 & 0,659 & 91,0 & 0,0 \\
\hline \multicolumn{8}{|l|}{ Strategies related to quantities and the size of stock } \\
\hline The "no stock" strategy (i.e. "just-in-time" strategy) & Y9 & $\mathrm{B}$ & 90 & 3,84 & 1,043 & 15,5 & 75,6 \\
\hline The multiple small quantity orders strategy & Y10 & B & 90 & 3,27 & 1,372 & 33,3 & 51,1 \\
\hline The occasional substantial order strategy & Y11 & A & 90 & 2,53 & 1,179 & 60,0 & 24,5 \\
\hline \multicolumn{8}{|l|}{ Strategies related to the number of sources of supply } \\
\hline $\begin{array}{l}\text { The most important strategic product is purchased from } \\
\text { one supplier only }\end{array}$ & Y12 & B & 90 & 2,53 & 1,342 & 55,6 & 28,9 \\
\hline $\begin{array}{l}\text { We have two or more alternative sources for } \\
\text { occasionally purchasing the most important strategic } \\
\text { products }\end{array}$ & Y13 & A & 90 & 3,80 & 1,100 & 11,1 & 64,4 \\
\hline \multicolumn{8}{|l|}{ Strategies related to marketing communication } \\
\hline $\begin{array}{l}\text { The strategy of occasional communication ("when } \\
\text { necessary") }\end{array}$ & $\mathrm{Y} 14$ & A & 90 & 3,76 & 0,933 & 11,1 & 71,1 \\
\hline $\begin{array}{l}\text { Together with the supplier we intensify competition } \\
\text { among suppliers }\end{array}$ & Y15 & B & 90 & 2,73 & 1,156 & 42,2 & 28,8 \\
\hline $\begin{array}{l}\text { The strategy of knowledge, information and technology } \\
\text { transfer ("know-how") }\end{array}$ & Y16 & B & 90 & 3,00 & 1,128 & 35,6 & 35,6 \\
\hline $\begin{array}{l}\text { The advertising strategy aimed at long-term } \\
\text { cooperation between the buyer and supplier }\end{array}$ & Y17 & B & 90 & 2,16 & 1,242 & 71,1 & 17,8 \\
\hline $\begin{array}{l}\text { Public relations strategy aimed at building a positive } \\
\text { image in the local and wider environment }\end{array}$ & Y18 & B & 90 & 2,76 & 1,228 & 46,7 & 33,4 \\
\hline $\begin{array}{l}\text { The strategies aimed at the promotion of purchasing } \\
\text { from the existing (chosen) suppliers in order to reach } \\
\text { favourable purchasing terms }\end{array}$ & Y19 & A & 90 & 3,58 & 1,270 & 22,2 & 62,3 \\
\hline $\begin{array}{l}\text { The strategies aimed at the promotion of the speed of } \\
\text { interpersonal communication with the supplier in order } \\
\text { to build long-term business relationships }\end{array}$ & Y20 & B & 90 & 3,42 & 1,076 & 24,4 & 53,4 \\
\hline \multicolumn{8}{|l|}{ Strategies related to processes } \\
\hline $\begin{array}{l}\text { Strategies of simultaneous harmonisation of processes } \\
\text { between the supplier and the organisation in the field of } \\
R \& D \text {, production, logistics, purchasing, sales, etc. }\end{array}$ & $\mathrm{Y} 21$ & B & 90 & 2,73 & 1,136 & 42,3 & 24,5 \\
\hline $\begin{array}{l}\text { Common development of strategies aimed at } \\
\text { development of human resources }\end{array}$ & $\mathrm{Y} 22$ & B & 90 & 1,98 & 0,965 & 75,6 & 6,6 \\
\hline Strategies aimed at mutual decision-making processes & $\mathrm{Y} 23$ & $\mathrm{~B}$ & 90 & 1,98 & 0,988 & 73,5 & 6,6 \\
\hline $\begin{array}{l}\text { Strategies aimed at developing corporate culture and } \\
\text { common values in both organisations }\end{array}$ & Y24 & B & 90 & 2,04 & 1,107 & 71,1 & 13,3 \\
\hline $\begin{array}{l}\text { Strategies aimed at the quality of business processes } \\
\text { between the supplier and buyer }\end{array}$ & Y25 & B & 90 & 3,00 & 1,168 & 31,1 & 35,6 \\
\hline
\end{tabular}

Legend:

* A - strategies characteristic of «transactional « marketing (classical buyer-supplier relationship)

$* \mathrm{~B}$ - strategies, characteristic of »relationship marketing «

** The results show the mean value of the frequency of implementation of purchasing marketing strategies in sampled organisations on a scale ranging from $1-\gg n$ ever implemented « to 5 - »always implemented «.

*** Organisations which rated the frequency of implementation of individual strategies with 2-very rarely and 1-never are included.

**** Organisations which rated the frequency of implementation of individual strategies with 5-always or 4-frequently are included. 
It can be seen from the table that organisations assessed the following purchasing marketing strategies highest or lowest:

- Within the set of strategies related to the purchased object the frequency value is the highest $(\mathrm{M}=3.49)$ in the strategy "Poka-Yoke" within the total quality management (TQM) and the lowest $(\mathrm{M}=2.40)$ in cooperation with the supplier in activities related to the product launch, modification of an existing product or removing products from the market.

- Within the set of strategies related to price and purchasing terms the frequency value is the highest $(\mathrm{M}=4.07)$ in $»$ the lowest purchasing price strategy with regard to other potential supplier for a certain product and the lowest $(\mathrm{M}=1.44)$ in the higher-than-average market price strategy.

- Within the set of strategies related to quantities and the size of stock the frequency value is the highest $(\mathrm{M}=3.84)$ in "just-in-time strategy" and the lowest $(\mathrm{M}=2.53)$ in the occasional substantial order strategy.

- The frequency value is higher $(\mathrm{M}=3.80)$ in $\gg$ the strategy of more alternative sources for purchasing the most important strategic products « than in the strategy of one supplier only $(\mathrm{M}=2.53)$.

- Within the set of strategies related to marketing communication the frequency value is the highest $(\mathrm{M}=3.76)$ in $\gg$ the strategy of occasional communication and the lowest $(M=2.16)$ in the advertising strategy aimed at long-term cooperation between the buyer and supplier.

- Within the set of strategies aimed at processes the frequency value is the highest $(M=3.00)$ in strategies of simultaneous harmonisation of processes between the supplier and the organisation and the lowest $(\mathrm{M}=1.98)$ in »common development of strategies aimed at development of human resources and »strategies aimed at mutual decision-making processes.

In addition to the results representing the frequency of implementation of purchasing marketing strategies of sampled organisations, we also ascertained the number of sampled organisations which implement certain strategies most or least frequently.

Our analysis was based on the results where the share of organisation exceeded $50 \%$ of sampled organisations, which is shown on Table 1 . Taking this into account, it can be stated that the majority of sampled organisations (more than 50\%) least frequently (MIN) implemented the following strategies:

- the strategy of cooperation with the supplier in the development of a new product of the organisation (the socalled "simultaneous engineering");

- cooperation with the supplier in activities related to the product launch, modification of an existing product or removing products from the market;

- $\quad$ the higher-than-average market price strategy;

- $\quad$ the occasional substantial order strategy;

- $\quad$ the strategy of purchasing from one supplier only;

- $\quad$ the advertising strategy aimed at long-term cooperation between the buyer and supplier;

- $\quad$ common development of strategies aimed at development of human resources;

- $\quad$ strategies aimed at mutual decision-making processes and

- $\quad$ strategies aimed at developing corporate culture and common values in both organisations.

It can be stated that purchasing marketing strategies with the lowest average value of the frequency of implementing is least frequently implemented by more than 50\% sampled organisations.

On the other hand, the majority of sampled organisations (more than 50\%) most frequently implement (MAX) the following strategies:

- $\quad$ the strategy of instantaneous purchases based on classical buyer-supplier relationships;

- $\quad$ the strategy of product standardisation;

- $\quad$ the strategy "Poka-Yoke" within the total quality management (TQM);

- $\quad$ the lowest purchasing price strategy with regard to other potential supplier for a certain product; 
- $\quad$ "just-in-time strategy;

- $\quad$ the multiple small quantity orders strategy;

- $\quad$ the strategy of alternative sources of supply for the most important strategic products;

- $\quad$ the strategy of occasional communication;

- $\quad$ the strategies aimed at the promotion of purchasing from the existing (chosen) suppliers in order to reach favourable purchasing terms and

- $\quad$ the strategies aimed at the promotion of the speed of interpersonal communication with the supplier in order to build long-term business relationships.

It can be stated that purchasing marketing strategies with the highest average frequency value is implemented by more than $50 \%$ of sampled organisations.

The analysis shows that sampled organisations implement such purchasing marketing strategies which are characteristic of »transactional « marketing, as well as some strategies characteristic for the concept of relationship marketing, i.e. aimed at building the concept with regard to the company's strategic supplier.

Analysis Of The Correlation Between Factors Of Relationship Strategy And The Frequency Of Implementation Of Purchasing Marketing Strategies

Checking the research hypotheses was done by the statistical method of discriminant analysis, in order to find out what is the correlation between series of independent variables $\mathrm{X}$ (i.e. groups of factors shaping relationships between sampled organisations) and individual aggregate dependent variables $\mathrm{Y}^{3}$, where:

- the aggregate Y (A) represents purchasing marketing strategies, characteristic of and prevailing in the conditions of classical buyer-supplier relationships between organisations and their suppliers (i.e. in conditions of implementing »transactional « marketing) and

- $\quad$ the aggregate Y (B) represents purchasing marketing strategies, characteristic of and prevailing in the conditions in which the organisation and its supplier implement long-term cooperative relationships (i.e. in conditions of »relationship marketing «), than 0,5 ;

By taking into account as statistically significant those canonical correlation coefficients which are larger

- $\quad$ if there are significant differences between the values of aggregate dependent variables (Y(A) and $Y(B)$ ), i.e. with regard to the frequency of implementing purchasing marketing strategies of type A and type B from the point of view of individual analysed series of independent variables (i.e. factors shaping the relationship strategy);

- $\quad$ which of the chosen independent variables add most towards the discrimination between both aggregate sets of dependent variables; standardised canonical coefficients of discriminant function were taken as statistically significant if they were higher than 0,5 or smaller than $-0,5$.

For each set of independent variables (X) we took into account the canonical discriminant function with the highest "eigenvalue" and the highest Chi-square test, which means that it makes it easier to discriminate between the sets of variables and, at the same time, the lowest Wilks' lambda.

Refer to Table 2 for factors in assessing the existing suppliers (X11).

\footnotetext{
${ }^{3}$ The aggregate dependent variable was calculated as the mean value of individual dependent variables. Y(A) represents aggregate mean value of the frequency of implementation of purchasing marketing strategies of type A and $\mathrm{Y}(\mathrm{B})$ represents the aggregate mean value of purchasing marketing strategies of type B.
} 
Table 2: Discriminant Analysis For A Series Of Independent Variables X11

\begin{tabular}{|c|c|c|c|c|c|c|c|}
\hline & Eigenvalue & $\begin{array}{c}\text { \% of } \\
\text { variance }\end{array}$ & $\mathbf{R}^{*}$ & $\begin{array}{c}\text { Wilks' } \\
\text { lambda }\end{array}$ & Chi-square & Df & Sig. \\
\hline $\mathrm{Y}(\mathrm{A})$ & 1,439 & 68,6 & 0,552 & 0,330 & 23,456 & 18 & 0,017 \\
\hline $\mathrm{Y}(\mathrm{B})$ & 1,455 & 69,9 & 0,542 & 0,297 & 18,799 & 27 & 0,087 \\
\hline
\end{tabular}

\begin{tabular}{|c|c|c|c|c|c|c|c|c|c|}
\hline \multicolumn{10}{|c|}{ Standardised Canonical Discriminant Function Coefficient } \\
\hline X11 & X111 & X112 & X113 & X114 & X115 & X116 & X117 & X118 & X119 \\
\hline $\mathrm{r}^{* *}(\mathrm{Y}(\mathrm{A}))$ & 0,537 & $-0,206$ & $-0,229$ & 0,326 & 0,568 & $-0,868$ & 0,785 & $-0,299$ & $-0,556$ \\
\hline $\mathrm{r} * *(\mathrm{Y}(\mathrm{B}))$ & $-0,021$ & $-0,156$ & 0,397 & $-0,220$ & 0,667 & 0,123 & 0,651 & $-0,655$ & $-0,220$ \\
\hline
\end{tabular}

$* \mathrm{R}$ - canonical correlation coefficient, indicating the strength of correlation between discriminate values and the group of independent variables;

** $\mathrm{r}$ - standardised canonical discriminate function coefficient

Because canonical correlation coefficients $(\mathrm{R})$ for both aggregate variables are higher than 0,5 , it can be said that there is a correlation between the value of individual factors for assessing the supplier and the frequency of implementation of purchasing marketing strategies of type A and type B.

Those organisations which frequently implement type A purchasing marketing strategies, assess their strategic supplier higher with regard to the following criteria: »supplier's capacity« (X111), »supplier's management « (X115) and »delivery in due time « (X117). The following factors are assessed lower: »product quality « (X116) and »supplier's ability to meet market requirements« (X119).

The research hypothesis H1a must be rejected because there is no significant negative correlation between weighted value of the majority of factors, with which organisations measure the attractiveness of existing strategic suppliers and the frequency of implementation of purchasing marketing strategies characteristic for and prevailing in conditions of classical buyer-supplier relationships (i.e. in conditions of »transactional « marketing).

Those organisations, which frequently implement type B purchasing marketing strategies, assess their strategic supplier higher with regard to the following criteria »supplier management« (X115) and »delivery in due time $\ll(\mathrm{X} 117)$, but lower with regard to the »purchasing price $«(\mathrm{X} 118)$.

The research hypothesis $\mathrm{H} 1 \mathrm{~b}$ must be rejected because there is no significant positive correlation between the weighted value of the majority of factors, with which organisations measure the attractiveness of existing strategic suppliers and the frequency of implementation of purchasing marketing strategies characteristic for and prevailing in conditions of »relationship marketing $«$.

Refer to Table 3 for factors of attractiveness in purchasing market for the organisation (X121).

Table 3: Discriminant Analysis For A Series Of Independent Variables X121

\begin{tabular}{|c|c|c|c|c|c|c|c|}
\hline & Eigenvalue & $\begin{array}{c}\text { \% of } \\
\text { variance }\end{array}$ & $\mathbf{R}^{*}$ & $\begin{array}{c}\text { Wilks' } \\
\text { lambda }\end{array}$ & Chi-square & Df & Sig. \\
\hline Y (A) & 1,255 & 71,5 & 0,451 & 0,233 & 11,982 & 14 & 0,046 \\
\hline Y (B) & 1,290 & 68,9 & 0,474 & 0,486 & 19,528 & 21 & 0,031 \\
\hline
\end{tabular}

\begin{tabular}{|c|c|c|c|c|c|c|c|}
\hline \multicolumn{8}{|c|}{ Standardised Canonical Discriminant Function Coefficient } \\
\hline $\mathbf{X 1 2 1}$ & $\mathbf{X 1 2 1 1}$ & $\mathbf{X 1 2 1 2}$ & $\mathbf{X 1 2 1 3}$ & $\mathbf{X 1 2 1 4}$ & $\mathbf{X 1 2 1 5}$ & $\mathbf{X 1 2 1 6}$ & $\mathbf{X 1 2 1 7}$ \\
\hline $\mathrm{r}^{* *}(\mathrm{Y}(\mathrm{A}))$ & 0,151 & 0,102 & $-0,971$ & 0,249 & 0,294 & 0,001 & 0,700 \\
\hline $\mathrm{r}^{* *}(\mathrm{Y}(\mathrm{B}))$ & 0,676 & $-0,235$ & $-0,673$ & 0,421 & $-0,217$ & 0,412 & 0,124 \\
\hline
\end{tabular}


As the canonical correlation coefficients $(\mathrm{R})$ are smaller than 0,5 for aggregate dependent variables $\mathrm{Y}(\mathrm{A})$ and $\mathrm{Y}(\mathrm{B})$, it can be said that there is no correlation between the degree of attractiveness of the purchasing market and the frequency of implementation of purchasing marketing strategies of organisations. Standardised canonical discriminant function coefficients for a series of dependent variables A, i.e. the aggregate $Y(A)$ and for a series of dependent variables B, i.e. aggregate $\mathrm{Y}(\mathrm{B})$ are in the majority of independent variables (i.e. factors of attractiveness of the purchasing market for the organisation) are statistically insignificant. Thus, research hypothesis $2 \mathrm{a}$ and $2 \mathrm{~b}$ must be rejected.

Refer to Table 4 for factors related to organisation's competitive position on the purchasing market (X122).

Table 4: Discriminant Analysis For A Series Of Independent Variables X122

\begin{tabular}{|c|c|c|c|c|c|c|c|}
\hline & Eigenvalue & $\begin{array}{c}\text { \% of } \\
\text { variance }\end{array}$ & $\mathbf{R}^{*}$ & $\begin{array}{c}\text { Wilks' } \\
\text { lambda }\end{array}$ & Chi-square & df & Sig. \\
\hline $\mathrm{Y}(\mathrm{A})$ & 1,313 & 79,6 & 0,589 & 0,205 & 12,774 & 16 & 0,048 \\
\hline $\mathrm{Y}(\mathrm{B})$ & 1,655 & 82,6 & 0,718 & 0,039 & 33,588 & 24 & 0,020 \\
\hline
\end{tabular}

\begin{tabular}{|c|c|c|c|c|c|c|c|c|}
\hline \multicolumn{8}{|c|}{ Standardised Canonical Discriminant Function Coefficient } \\
\hline $\mathbf{X 1 2 2}$ & $\mathbf{X 1 2 2 1}$ & $\mathbf{X 1 2 2 2}$ & $\mathbf{X 1 2 2 3}$ & $\mathbf{X 1 2 2 4}$ & $\mathbf{X 1 2 2 5}$ & $\mathbf{X 1 2 2 6}$ & $\mathbf{X 1 2 2 7}$ & $\mathbf{X 1 2 2 8}$ \\
\hline $\mathrm{r}^{* *}(\mathrm{Y}(\mathrm{A}))$ & $-0,053$ & $-0,584$ & 0,771 & 0,287 & $-0,060$ & 0,185 & $-0,154$ & 0,563 \\
\hline $\mathrm{r}^{* *}(\mathrm{Y}(\mathrm{B}))$ & $-0,010$ & 0,011 & $-0,203$ & 0,072 & 0,326 & 0,324 & 0,537 & $-0,622$ \\
\hline
\end{tabular}

Because canonical correlation coefficients $(\mathrm{R})$ for both dependent variables are higher than 0,5 , it can be said that there is a correlation between factors for assessing company's competitive position and the frequency of implementation of both, type A and type B purchasing marketing strategies.

Those organisations which frequently implement type A purchasing marketing strategies reach a better competitive position on the purchasing market. The following two factors are taken into consideration: »the ratio between supply costs and supply value « (X1223) and »demand price elasticity « (X1228). Their competitive position is relatively weaker if $»$ switching costs« are taken into consideration (X1222).

The research hypothesis $3 \mathrm{a}$ can be confirmed because there is a significant positive correlation between the competitive position (i.e. the majority of factors for assessing the organisation's marketing position) and the frequency of implementation of purchasing marketing strategies characteristic for and prevailing in conditions of classical buyersupplier relationships (i.e. in conditions of $»$ transactional $\ll$ marketing).

Those organisations, which frequently implement type B purchasing marketing strategies, have a better relative competitive position related to »market informatisation « (X1227) and a weaker competitive position related to the factor »demand price elasticity« (X1228).

The research hypothesis $\mathrm{H} 3 \mathrm{~b}$ must be rejected because there is no significant negative correlation between the competitive position (i.e. the majority of factors for measuring the level of sampled company's competitive position) of organisations on the purchasing market and the frequency of implementation of purchasing marketing strategies characteristic for and prevailing in conditions of »relationship marketing «.

Refer to Table a5 for factors related to organisation's bargaining power and its manoeuvring space (X2).

Because canonical correlation coefficients $(\mathrm{R})$ for both dependent variables are higher than 0,5 , it can be said that there is a correlation between factors related to the organisation's bargaining power and the frequency of implementation of both, type A and type B purchasing marketing strategies. 
Table 5: Discriminant Analysis For A Series Of Independent Variables X2

\begin{tabular}{|c|c|c|c|c|c|c|c|}
\hline & Eigenvalue & $\begin{array}{c}\text { \% of } \\
\text { variance }\end{array}$ & $\mathbf{R}^{*}$ & $\begin{array}{c}\text { Wilks' } \\
\text { lambda }\end{array}$ & Chi-square & df & Sig. \\
\hline $\mathrm{Y}(\mathrm{A})$ & 1,420 & 68,0 & 0,544 & 0,267 & 18,036 & 26 & 0,087 \\
\hline $\mathrm{Y}(\mathrm{B})$ & 1,911 & 72,8 & 0,737 & 0,037 & 39,603 & 39 & 0,044 \\
\hline \multicolumn{7}{|c|}{ Standardised Canonical Discriminant Function Coefficient } \\
\hline X2 & $\mathbf{X 2 1}$ & $\mathbf{X 2 2}$ & $\mathbf{X 2 3 1}$ & $\mathbf{X 2 3 2}$ & $\mathbf{X 2 3 3}$ \\
\hline $\mathrm{r}^{* *}(\mathrm{Y}(\mathrm{A}))$ & $-0,168$ & $-0,574$ & $-0,434$ & $-0,181$ & $-0,160$ \\
\hline $\mathrm{r}^{* *}(\mathrm{Y}(\mathrm{B}))$ & 0,051 & 0,360 & 0,119 & 0,240 & 0,134 \\
\hline
\end{tabular}

The research hypotheses $\mathrm{H} 4 \mathrm{a}$ and $\mathrm{H} 4 \mathrm{~b}$ must be rejected because both standardised canonical discriminant function coefficients of the independent variable X21, i.e. »organisation's risk orientation « are statistically insignificant.

The research hypothesis 5a can be confirmed because there is a negative correlation between the degree of organisation's cooperation orientation and the frequency of implementation of those purchasing marketing strategies, characteristic of and prevailing in conditions of »transactional« marketing (i.e. type A strategies).

The research hypothesis $\mathrm{H} 5 \mathrm{~b}$ must be rejected because there is no statistically significant correlation between the standardised canonical coefficient for the independent variable X22 (i.e. organisation's cooperation orientation) and the aggregate dependent variable $\mathrm{Y}(\mathrm{B})$.

Similarly, the research hypotheses $\mathrm{H} 6 \mathrm{a}$ and $\mathrm{H} 6 \mathrm{~b}$ can not be confirmed because standardised canonical discriminant function coefficients for the series of independent variables X23 (i.e. the size of bargaining power) are statistically insignificant.

Because canonical correlation coefficients $(\mathrm{R})$ for both dependent variables are higher than 0,5 , it can be said that there is a correlation between the assessment of individual factors related to the size of company's transactional assets and the frequency of implementation of both, type A and type B purchasing marketing strategies

Refer to Table 6 for factors related to the size of organisation's transactional assets (X3).

Table 6: Discriminant Analysis For A Series Of Independent Variables X3

\begin{tabular}{|c|c|c|c|c|c|c|c|}
\hline & Eigenvalue & $\begin{array}{c}\text { \% of } \\
\text { variance }\end{array}$ & $\mathbf{R}^{*}$ & $\begin{array}{c}\text { Wilks' } \\
\text { lambda }\end{array}$ & Chi-square & df & Sig. \\
\hline $\mathrm{Y}(\mathrm{A})$ & 1,340 & 78,0 & 0,504 & 0,381 & 15,001 & 14 & 0,037 \\
\hline $\mathrm{Y}(\mathrm{B})$ & 1,732 & 87,4 & 0,767 & 0,138 & 41,731 & 21 & 0,005 \\
\hline
\end{tabular}

\begin{tabular}{|c|c|c|c|c|c|c|c|}
\hline \multicolumn{7}{|c|}{ Standardised Canonical Discriminant Function Coefficient } \\
\hline $\mathbf{X 3}$ & $\mathbf{X 3 1}$ & $\mathbf{X 3 2}$ & $\mathbf{X 3 3}$ & $\mathbf{X 3 4}$ & $\mathbf{X 3 5}$ & $\mathbf{X 3 6}$ & $\mathbf{X 3 7}$ \\
\hline $\mathrm{r}^{* *}(\mathrm{Y}(\mathrm{A}))$ & $-0,886$ & 0,136 & 0,941 & $-0,763$ & $-0,563$ & $-0,575$ & 0,336 \\
\hline $\mathrm{r}^{* *}(\mathrm{Y}(\mathrm{B}))$ & 0,543 & 0,558 & 0,028 & 0,628 & 0,687 & 0,140 & 0,037 \\
\hline
\end{tabular}

Those organisations, which frequently implement type A purchasing marketing strategies, mainly exchange "tangible" product components with their supplier (objects of transaction) (X31), they do not cooperate with the chosen supplier in the field of technology (X34) nor in the field of management (X35). From the point of view of values and corporate culture, buyer's and supplier's organisations differ substantially (X36).

The research hypothesis H7a can be confirmed because there is a negative correlation between the size of organisation's transactional assets (i.e. the majority of factors used for assessing the size of company's transactional 
assets) and the frequency of implementation of purchasing marketing strategies characteristic for and prevailing in conditions of classical buyer-supplier relationships (i.e. in conditions of »transactional « marketing).

The research hypothesis $\mathrm{H} 7 \mathrm{~b}$ can also be confirmed because organisations, which frequently implement type B purchasing marketing strategies, also exchange with their suppliers services and »know-how «, values, culture, behaviour and business thinking (X31). Their connection with the supplier is based on a middle-term and long-term agreement (X32), they cooperate with the supplier in the field of technology (X34) and management (X35).

There is a positive correlation between the size of transactional assets (i.e. the majority of factors used for assessing the size of company's transactional assets) and the frequency of implementation of purchasing marketing strategies characteristic for and prevailing in conditions of »relationship marketing «.

\section{CONCLUSION AND STRATEGIC IMPLICATIONS}

In analysing the frequency of purchasing marketing strategies in sampled organisations, i.e. organisations from Slovenia with more than 500 employees (large organisations) - regardless of the characteristics of the factors shaping the relationships of these organisations with their strategic suppliers - we found that the frequency of implementation is highest in those strategies that give direct fast, short-term (or instantaneous) effects on the organisation's business success or may lead to savings related to purchasing (i.e. to lowering purchasing costs and, subsequently, to lowering the production costs) and, at the same time, ensure purchasing security and lower the level of business risk. Among the most frequently implemented strategies are the total quality management strategy, the lowest purchasing price strategy, »just-in-time « strategy, the strategy of multiple purchasing sources for a certain Aproduct, the strategy of occasional communication with the supplier and the strategy of harmonisation of the quality of business processes. These strategies are implemented by the majority of sampled organisations.

It was found that large organisations in Slovenia develop certain strategies with their strategic suppliers characteristic for the concept of »relationship marketing «, but the prevailing concept is still the classical buyersupplier concept, characteristic for »transactional« marketing.

If we include the influence of factors, which are determining relationships of organisations with their strategic suppliers in the analysis, on the implementation of purchasing marketing strategies, the following was found: the frequency of implementation of certain purchasing marketing strategies is connected with the value given by the organisation to its strategic suppliers, with factors related to the organisation's market position on the purchasing market, with the organisation's bargaining power and the size of its transactional assets, but is not connected with factors related to the attractiveness of the purchasing market for the organisation.

A thorough insight into standardised canonical discriminant function coefficients with regard to individual groups of factors shows that:

- $\quad$ the weighted value of individual factors, as well as the contents of factors, used by organisations for assessing their strategic suppliers, had a varied impact on the frequency of implementation of both types of purchasing marketing strategies (type A and type B);

- a better competitive position of an organisation reduces the tendency to implement purchasing marketing strategies, characteristic for the concept of »relationship marketing « (even in cases of strategic suppliers with which organisations want to establish a long-term relationships);

- $\quad$ higher organisation's risk orientation does not have direct effects (but with likely indirect effects) on the frequency of a certain type of purchasing marketing strategy;

- $\quad$ organisations, which are oriented towards cooperation, more frequently implement such purchasing marketing strategies which are characteristic for the concept of »relationship marketing «;

- $\quad$ the type of strategy is not determined by the size of bargaining power;

- The size of transactional assets of an organisation is most clearly and distinctly connected with the implementation of a certain type of purchasing marketing strategies, as organisations with large transactional 
assets tend to implement purchasing marketing strategies characteristic for the concept of »relationship marketing $\ll$.

It can be assumed that the purchasing orientation of large organisations in Slovenia is still more tacticaloperational than strategic. Despite long-term orientation of relationships with their strategic suppliers, organisations still seek short-term benefits and greater purchasing efficiency and are less likely to be oriented towards long-term success.

Our research revealed that organisations willing to implement purchasing marketing strategies in relationships to their strategic suppliers will have to achieve the following:

- $\quad$ include the planning of strategic purchasing marketing, its implementation and control in the context of purchasing function;

- $\quad$ adapt purchasing marketing strategies to conditions in their environment by establishing and retaining longterm relationships with their strategic suppliers by implementing suitable purchasing marketing strategies, which are likely to foster such relationships;

- $\quad$ long-term success orientation in the field of purchasing function in an organisation should be, in conditions of long-term cooperation with strategic suppliers, connected with the creation of such strategic goals, which will enable mutual benefits for both participants in the relationship.

\section{REFERENCES}

1. Anders, W. (1992), Strategische Einkaufsplannung, Peter Lang, In.

2. Anderson, J.C., Hakansson, H., Johanson, J. (1994), Dyadic Business Relationships Within Business Network Context; Journal of Marketing, Vol. 58; pp. 1-13.

3. Anderson, J.C., Narus, J.A. (1990), A model of distributor firm and manufacturing firm working relationships; Journal of Marketing; Vol. 54; January; pp. 42-58.

4. Anderson, E. W., Weitz, B. (1987), Determinant of Continuity in Conventional Industrial Channel Dyads; unpublished; The Wharton School; University of Pennsylvania.

5. Baily P., Farmer, D., Jessop D., Jones D. (1994), Purchasing Principles and Management; Pitman Publishing London.

6. Bergen, M., Dutta, S., Walker, O. C. (1992), Agency Relationships in Marketing: A Review of the Implications and Applications of Agency and Related Theories; Journal of Marketing; Vol. 56; July; pp. 124.

7. Cannon, J. P., Pereault Jr., W. D. (1999), Buyer-Seller Relationships in Business Markets; Journal of Marketing Research; Vol. 36; November; pp. 439-460.

8. Christopher, M., Payne, A., Ballantyne, D. (1991), Relationship Marketing: Bringing Quality, Customer Service and Marketing Together; Butterworth-Heinemann, Oxford.

9. Dwyer, F. R., Schurr, P. H., Oh, S. (1987), Developing Buyer - Seller Relationships; Journal of Marketing, April; pp. 11-27.

10. Gummesson, E. (1995), The New Marketing - Developing Long-Term Interactive Relationships; in McDonald, M., Marketing Strategies; New Approaches, New Techniques; Pergamon; pp. 83-101.

11. Han, S. L., Wilson, D. T., Dant, S. P. (1993), Buyer - Supplier Relationships Today; Industrial Marketing Management 22; pp. 331-338.

12. Iacobucci, D. (1996), Networks in Marketing; Thousand Oaks, CA: Sage Publications.

13. Iršič, M. (1998) Strategije nabavnega marketinga organizacije v razmerah razvitih oblik marketinga povezav; doktorska disertacija; EPF, Maribor.

14. Iršič, M. (2001). How Developed are the Relationships of the Slovenian Companies with their Suppliers Modelling Approach; Der Markt; Nr. 157/158; pp. 66-74.

15. Jackson, B. B. (1985), Winning and Keeping Industrial Customers; Lexington Bks., Lexington, MA.

16. Johnson, M.D., Selnes, F. (2004), Customer Portfolio Management: Toward a Dynamic THeory of Exchange Relationships; Journal of Marketing; Vol. 68; April; pp. 1-17. 
17. Kohli, A. (1989), Determinants of Influence in Organizational Buying: A Contingency Approach; Journal of Marketing, July; pp. 50-65.

18. Koppelmann, U. (1993), Beschaffungsmarketing, Springer-Verlag.

19. Kraljič, P. (1983), Purchasing must become Supply Management, Harvard Business Review, 61, Sept. - Oct; pp. 109-117.

20. Levy, M., Grewal, D. (2000), Supply CHain Management in Networked Economy; Journal of Retailing; Vol. 76; pp.415-429.

21. Low, B. K. H. (1995), Long - Term Relationship in Industrial Marketing; Reality or Rhetoric? Industrial Marketing Management 25; pp. 23-35.

22. Morgan R.M., Hunt, S.D. (1994), The Commitment-Trust Theory of Relationship Marketing; Journal of Marketing, Vol. 58., pp. 20-25.

23. Payne, A. (1995), Relationship Marketing Strategy; Handbook of Management; The Financial Times; ed. Crainer, S.; FT Pitman Publishing.

24. Puto, C. P., Patton III., W. E., King, R. H. (1985), Risk Handling Strategies in Industrial Vendor Selection Decisions; Journal of Marketing; Winter; pp. 89-98.

25. Qualls, W. J., Puto, C. P. (1989), Organizational Climate and Decision Framming: An Integrated Approach to Analyzing Industrial Buying Decisions; Journal of Marketing Research; Vol. 26; pp. 179-192.

26. Thorelli, H. B. (1986), Networks: Between Markets and Hierarchies; Strategic Management Journal; Vol. 7; pp. 37-51.

27. Wathne, K.H., Heide, J.B. (2004), Relationship Governance in a Supply Chain Network; Journal of Marketing; Vol. 68; January; pp. 73-89.

28. Westbrook, K., W. (1996), Risk Coordinative Maneuvers During Buyer - Seller Negotiations; Industrial Marketing Management; No. 25; pp. 283-292.

\section{NOTES}

